\title{
Urška Rihtaršič
}

Filozofska fakulteta, Univerza v Ljubljani

Faculty of Arts, University of Ljubljana

\section{Med telesom in razumom. Izvajalec klasične glasbe $\mathrm{v}$ postmodernizmu Between Body and Mind. Classical Music Performer in the Postmodern Era}

Prejeto: 18. oktober 2016

Sprejeto: 7. december 2016

Ključne besede: romantični virtuoz, modernistični virtuoz, postmoderni virtuoz

\section{IZVLEČEK}

Obstajajo trije idealni tipi (Max Weber) izvajalca zahodne klasične glasbe. Ti tipi opredeljujejo njegov odnos do drugih akterjev glasbene prakse - skladatelja, glasbenega dela in publike. Romantičnemu virtuozu glasba predstavlja sredstvo, prek katerega navdušuje občinstvo s svojo osebnostjo in telesnostjo. Nasprotno pa morata osebnost in telesnost modernističnega virtuoza ostati čim bolj skriti, da se lahko v polnosti izrazi glasbeno delo (Lydia Goehr), ki je plod intelektualnega dela skladatelja. Postmoderni virtuoz skladno z značilnostmi dobe kombinira lastnosti prej obstoječih tipov (pastiš, palimpsest), poleg tega pa ga bistveno opredeljuje vpetost umetnosti $\mathrm{v}$ sistem poznega kapitalizma in postmoderna izguba specifičnosti estetske izkušnje (Fredric Jameson).
Received: 18th October 2016

Accepted: 7th December 2016

Keywords: romantic virtuoso, modern virtuoso, postmodern virtuoso

\section{ABSTRACT}

There are three ideal types (Max Weber) of a western classical music performer. These types describe the performer's relationship to composer, musical work and audience. The romantic virtuoso uses music as a means to impress audiences with his personality and corporeality. On the contrary, personality and corporeality of the modernist virtuoso must remain hidden in order to highlight the musical work (Lydia Goehr), which is the result of the composer's intellectual work. In accordance with the general features of postmodern era, the postmodern virtuoso combines and mixes characteristics of previously existing types (pasticcio, palimpsest). This type is also highly defined by the incorporation of postmodern art into the system of late capitalism and the postmodern loss of the specificity of aesthetic experience (Fredric Jameson). 


\section{Uvod}

Ustvarjanje glasbe je družbena dejavnost. Družbene specifike vplivajo na značilnosti v glasbi in hierarhična razmerja v glasbi odslikavajo socialna razmerja. Zahodno družbo je v vseh njenih zgodovinskih oblikah zaznamovala stroga hierarhizacija, kar se odraža tudi v strukturi glasbe in glasbene prakse. V kar preveč očitni obliki se takšna hierarhizacija kaže v zgradbi in prostorski formaciji simfoničnega orkestra. Manj očithe, a ravno tako pomembne odnosne pozicije pa se oblikujejo med skladateljem, glasbenim delom, izvajalcem in občinstvom. Raziskovanje razmerij med akterji glasbene prakse nam tako lahko pove veliko o strukturi družbe, v kateri so se tovrstna razmerja oblikovala, ter o položaju umetnosti in glasbe znotraj nje.

V pričujočem prispevku se bom zgoraj omenjenemu kavzalnemu razmerju približala z nasprotne strani. Prek analize socialnih in kulturnih specifik, ki so bistveno vplivale na razvoj in družbeno pozicijo umetnosti in glasbe, bom poskušala določiti in razložiti položaj izvajalca zahodne klasične glasbe v razmerju do drugih akterjev glasbene prakse. Pri tem se bom osredotočila na izvajalca kot solista in kot člana komornih zasedb; odnosom v orkestru se ne bom posvečala.

\section{Specifika zahodne klasične glasbe}

Številni sociologi in etnomuzikologi kot eno osnovnih karakteristik zahodne glasbene kulture navajajo delitev na avtorstvo in izvedbo oz. opozicijo med formalno strukturo in njeno zvočno realizacijo. ${ }^{1} \mathrm{~V}$ ekstremnih primerih tovrstnega ločevanja je zvočna realizacija razumljena zgolj kot ,nujno zlo', prek katerega se razkrije čista struktura glasbenega dela. Opozicijo dodatno zaostruje v zahodni družbi tradicionalno prisoten kartezijanski dualizem, ki predpostavlja ločevanje človeške entitete na duh (oz. razum; v glasbenem kontekstu je produkt razuma formalna struktura dela) in telo (inferiorno razumu; v glasbenem kontekstu je nujno povezano z izvedbo). Poljski fenomenolog Roman Ingarden je glasbeno delo opredelil kot intencionalni objekt. V trenutku kreacije vse faze objekta simultano obstajajo v razumu skladatelja, katerega intencionalnost definira identiteto objekta. ${ }^{2}$ Izvedba tako v nobenem primeru ne more biti konstitutivni del objekta, saj gre pravzaprav za njegovo destrukcijo oz. časovno porazdelitev realno hkrati-obstoječih elementov. Enako po Ingardnu drži za partituro - notacija ni nikoli dovolj specificirana, da bi lahko v polnosti izrazila intencionalni objekt. ${ }^{3}$

Ingardnov intencionalni objekt predstavlja skrajni primer, ki pa naj služi za ilustracijo temeljnega razcepa zahodne klasične glasbe, torej razcepa na avtorstvo in izvedbo. Tega je v veliki meri omogočil šele razvoj notne pisave, ki je glasbo ločila od

1 Paul Théberge, Any sound you can imagine: making music/consuming technology (Hanover, NH: Wesleyan University Press., 1997), 189; Charles Keil in Steven Feld, Music grooves (Chicago: The University of Chicago Press., 1994), 55; Jože Vogrinc, Popularna godba. Eseji o poslušanju (Maribor: Subkulturni azil, 2012), 31.

2 Daniel Leech-Wilkinson, "The changing sound of music: approaches to studying recorded musical performances« (http://www. charm.rhul.ac.uk/studies/chapters/intro.html, 10. 3. 2016), 2-11.

3 Prav tam. 
izvajalčevega telesa. ${ }^{4}$ Vendar pa je bila vloga notacije sprva predvsem deskriptivna partitura ni predstavljala prostora komponiranja, pač pa je služila predvsem kot opora spominu, torej kot prostor zapisovanja $\mathrm{v}$ praksi že obstoječih glasbenih idej. Tudi, ko je notacija postala preskriptivna, pa cilj še ni bilo ustvarjanje fiksnih glasbenih objektov oz. glasbenih del. Še v 16. stoletju partitura ni bila končni cilj skladateljskega dela, pač pa predvsem tehnični pripomoček, s katerim je skladatelj »načrtoval vloge, ki jih je bilo treba izvesti ${ }^{5}$ Do 17 . stoletja je bilo veliko podrobnosti izvedbe prepuščenih interpretu - od izvedbe generalbasa pa do relativne svobode pri improvizaciji melodičnih linij. Vse do 18. stoletja je bila tudi zahodna klasična glasba, kakor večina drugih glasb, predvsem performativna umetnost. ${ }^{6}$ Skladatelji so kot končni rezultat svojega kompozicijskega procesa dojemali izvedbo. Kadar je bilo izvedb ene skladbe več, je vsaka posamezna izvedba predstavljala svojevrsten fenomen - posledično so se lahko v določenih podrobnostih precej razlikovale. Še v 19. stoletju je Gioacchino Rossini predstavljal tip skladatelja, „čigar dela so v funkciji čim bolj prepričljive glasbene izvedbe. Tej se seveda lahko v konkretni produkciji prilagajajo, izvajalec pa je pri tem relativno svoboden ". Takšno prilagajanje je tudi posledica slave, ki so jo v tistem času dosegali virtuozni izvajalci - ravno ti so bili pogosto razlog, da je občinstvo množično obiskovalo operne predstave in koncerte.

Rossinijevski tip skladatelja pa najde svojo močno opozicijo v Ludwigu van Beethovnu - njegova dela predstavljajo "nespremenljive spomenike, katerih interpretacija je vedno le v funkciji razlage nedotakljivega dela.$^{8}$ Prepričanje, da naj bi zapisani tekst v celoti določal interpretacijo, pa v resnici ni novo. Že Aristotel je v Poetiki idejni obliki eksistence umetnosti pripisoval prednost pred njeno realizacijo.? Prav Beethovnova pozna dela, ki jih je skladatelj napisal v obdobju popolne oglušelosti, tako predstavljajo »ideal tovrstnega platonističnega vrednotenja glasbe« - Beethoven je doživljal glasbo kot »čisto idejo in sploh ni potreboval fizikalnega zvoka kot njenega nujno nepopolnega posnetka«. ${ }^{10}$

Z razvojem preciznejše notacije je skladatelj pridobival vse bolj ekskluzivno odgovornost za detajle $\mathrm{v}$ kompoziciji, hkrati pa mu je natančno zapisovanje omogočilo, da je bil vse manj vključen v proces izvedbe svojih del. Ker so bile skladbe natančno notirane, jih je moral izvajalec tudi natančno izvesti. Tako je bila ustvarjena in utrjena vloga skladatelja kot ustvarjalnega genija, hkrati pa je prihajalo do razvrednotenja vloge glasbenika inštrumentalista oz. poustvarjalca. ${ }^{11}$ Klasična glasba se je v zahodnih kulturah pozicionirala kot intelektualna dejavnost, ki jo z ustvarjanjem glasbenih del poganjajo skladatelji. Partitura, ki je v prejšnjih stoletjih predstavljala zgolj prostor zapisa že obstoječe glasbene praske ali pripomoček za komponiranje, od 18. stoletja naprej

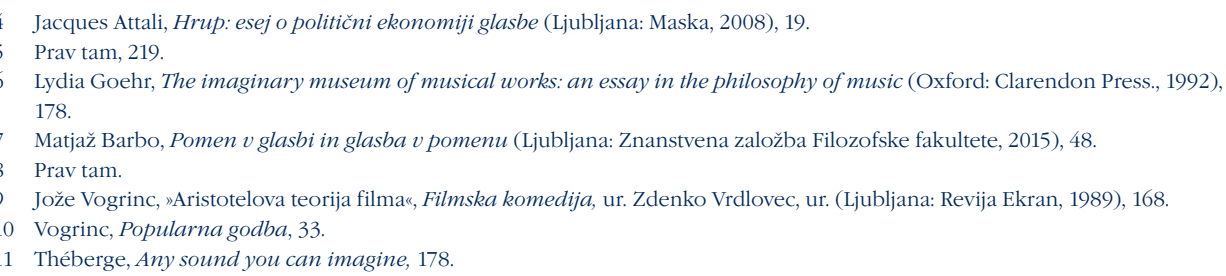


simbolizira glasbo samo. ${ }^{12}$ Čeprav se je občinstvo tradicionalno navduševalo nad virtuoznostjo izvajalcev, pa je danes partitura tista, ki je simbolizirala trajen in posledično višje vrednoten umetniški izraz. Pri tem gre za posledico nekaterih družbenih dogajanj, ki so vzpostavile skladatelja in glasbeno delo kot superiorno izvajalcu.

\section{Vstop umetnosti $v$ kapitalistični sistem in razvoj romantične virtuoznosti}

Pred 18. stoletjem sta v zahodnem svetu družbeni pomen glasbene prakse in njena legitimacija izhajala iz funkcije, ki jo je glasba opravljala v kontekstu drugih družbenih institucij, predvsem religioznih in aristokratskih. Te so lahko odločale o njeni vsebini, obliki in pogojih produkcije. Umetniki večinoma niso ustvarjali iz lastnega vzgiba, pač pa so bili popolnoma integrirani v cerkveno ali aristokratsko okolje. Tradicionalna družba tako ni poznala pojma umetnikove subjektivnosti ${ }^{13}$ in kadar so glasbena dela izdajali v notni obliki, se na prvi strani ni pojavilo skladateljevo ime, pač pa priložnost oz. oseba, za katero je bilo delo napisano. Za ,lastnika' glasbe se tako ni štel njen avtor, pač pa je pripadala tistemu, ki je delo naročil. ${ }^{14}$

Obdobje po letu 1800 pa na področje umetnosti prinese radikalno spremembo. Z vzponom meščanskega razreda in posledičnim razmahom kapitalističnega trga postane tudi umetniška proizvodnja vpeta v načela tržne ekonomije. Umetnost se tako osvobodi zunanje legitimacije, a hkrati postane podrejena logiki profita in konkurenčnosti. Osebni odnos, značilen za razmerje med umetnikom in njegovim mecenom se umakne anonimnemu svobodnemu tržišči, ki je zasnovano na logiki profita in konkurenčnosti. ${ }^{15}$ Meščanstvo, ki je z nakupom vstopnic financiralo novo rojeno koncertno dejavnost, je imelo posledično moč določati njeno obliko in vsebino. Ker je hlepelo po spektakularnosti in pompoznosti, ki bi simbolizirala njegovo novo pridobljeno družbeno in politično moč, je morala biti tudi glasba vse bolj spektakularna in pompozna. Orkestri so postajali večji in notranje vse bolj diferencirani, inštrumenti so se razvijali v smeri večjega zvočnega volumna in posledično težjega obvladovanja, pojavili so se zvezdniški virtuozi. ${ }^{16}$

Virtuozni recital, ki ga je leta 1840 v Londonu ,izumil‘ Franz Liszt, ${ }^{17}$ obuja v klasični glasbi dolgo izgubljeno in zatajevano povezavo s telesnostjo in ritualnostjo. Lawrence Kramer po vzoru Mihaela Bahtina izvore virtuoznosti in zvezdništva išče v predmodernih festivalskih praksah, pri katerih še ni jasne ločnice med izvajalci in gledalci - vsi udeleženci so hkrati virtuozi in njihovi oboževalci. S poblagovljenjem glasbe se je romantični virtuoz ločil od publike, s čimer je postal recital družbeno regulirana verzija

12 Leech-Wilkinson, "The changinh sound of music", 2-3.

13 Aleš Debeljak, Na ruševinah modernosti: institucija umetnosti in njene zgodovinske oblike (Ljubljana: Znanstveno in publicistično središče, 1999), 23.

14 Barbo, Pomen v glasbi in glasba v pomenu, 41

15 Debeljak, Na ruševinah modernosti, 27, 40, 79.

16 Jacques Attali, Hrup: esej o politični ekonomiji glasbe (Ljubljna: Maska, 2008), 69.

17 Goehr, Imaginary museum of musical works, 240. 
festivala. ${ }^{18}$ Dejstvo, da je za obisk recitala potrebno plačati vstopnico in da je dogodek podrobno načrtovan, pa ne zmanjšuje njegovega učinka, ampak zgolj povečuje občutek ritualnosti in ločenosti od vsakdanje rutine. V tem kontekstu je cilj virtuoznega nastopa predvsem množična katarza, ki jo na koncu dosežeta tako virtuoz kot njegovo občinstvo. ${ }^{19}$ Skupna katarza je mogoča, ker se občinstvo popolnoma poistoveti z virtuozom, kar potrjujeta tako psihoanalitična teorija ${ }^{20}$ kot tudi pred kratkim izvedene nevro-psihološke študije. Kalifornijska univerza UCLA je potrdila obstoj živčnega procesa, ki so ga poimenovali mirroring (zrcaljenje). V procesu zrcaljenja naši nevroni oponašajo dogajanje v svoji okolici, kar vpliva tako na fizični kot tudi emocionalni Živčni sistem. Če vidimo nekoga, ki se nasmehne, se bodo sprožili živci, povezani s smejalnimi mišicami, pa tudi možganski živci, povezani z občutkom sreče. Empatija je torej vgrajena v človeški nevronski sistem in proces zrcaljenja omogoča identifikacijo z virtuozom, saj lahko dejansko občutimo boj in zmagoslavje glasbenika na odru. ${ }^{21}$

Romantični virtuozi so se zavedali pomembnosti lastnega telesa pri komunikaciji z občinstvom. Prototip romantičnega virtuoza Franz Liszt je telesne geste, ki so sicer nujno potrebne za proizvajanje zvoka na klavirju, še dodatno dramatiziral, do klaviature pa je vzpostavljal skoraj erotični odnos. Na koncertnih turnejah se je zanašal na tri atribute, vse tesno povezane $z$ njegovo telesnostjo: značilen in prepoznaven kostum, rokavice, ki jih je pred začetkom koncerta odvrgel, da so si jih oboževalci lahko prisvojili kot trofejo in spomin ter lase, ki so mu med igranjem vihrali okrog glave. ${ }^{22}$

Romantični virtuoz je torej glasbo izkoriščal kot sredstvo, s katerim je dokazoval svojo superiornost in tako navduševal množice, svojo javno podobo pa je gradil na poudarjeni telesnosti. Nasproti pa mu je stopila kultura, ki je pod vplivom ločevanja na avtorstvo in izvedbo ter koncepta glasbenega dela (glej naslednje poglavje) glasbo dojemala vse bolj kot intelektualno, in ne kot telesno dejavnost. Ni torej presenetljivo, da je bil romantični virtuoz v klasičnem kontekstu hitro označen za ,šarlatana', ki sta mu pomembni zgolj hitrost in tehnika, virtuozni recital pa za popularni spektakel, primerljiv s cirkuško predstavo. ${ }^{23} \mathrm{~V}$ kontekstu resne glasbe je takšen tip virtuoza postal neprimeren - svoje mesto pa je uspešno našel v popularni kulturi.

\section{Elitizem, ideologija Werktreue in razvoj modernistične virtuoznosti}

Meščanstvo, ki je sprva sestavljalo enoten družbeni sloj, se je v 19. in 20. stoletju notranje jasno diferenciralo. Na eni strani so bili srednji in višji meščanski sloji, ki so jih zaznamovale funkcije "pridobitništva in gmotnega lastništva", na drugi strani pa je stala

\footnotetext{
18 Lawrence Kramer, "The virtuoso body; or, the two births of musical performance«, Critical Musicological Reflections, ur. Stan Hawkins (Burlington: Ashgate, 2012), 242.

19 Kramer, »The virtuoso body«, 238.

20 Za psihoanalitično razlago virtuoznega nastopa glej Kramer, »The virtuoso body«, 238-239.

21 David Byrne, How music works (Edinburgh, London: Canongate, 2013), 342.

22 Kramer, »The virtuoso body«, 238-239.

23 Goehr, Imaginary museum of musical works, 233.
} 
intelektualno-umetniška elita, ki je zastopala "funkcije kulture, duha in izobrazbe«. ${ }^{24}$ Slednja je svojo pozicijo začela razumevati kot »superiorno glede na banalne zakonitosti profita ter mehanizme ponudbe in povpraševanja«, ${ }^{25}$ kakršnim so se po uspešno prilagajali tudi nekateri umetnosti fenomeni, kot sta popularni roman in romantični virtuoz. Romantika je torej na glasbenem področju zaslužna tako za izoblikovanje ideala romantičnega virtuoza, ki postavi temelje za vzpostavitev koncepta $z v e z d e,{ }^{26}$ kot tudi za nasprotujoče ,moderno‘ razumevanje umetniških del, ki izražajo »radikalni odmik od popularnosti in množičnega občinstva«. ${ }^{27}$ Ta se v polnosti uresniči v obdobju visokega modernizma, ko se kot ključna estetska kriterija uveljavita individualnost in novost, kot posledica pa naraščata intelektualizem in kompleksnost umetniških postopkov. Umetnost tako postaja dostopna vse ožjemu krogu izobraženih posameznikov.

Dokler je glasbo opredeljevala zunanja legitimacija, je bilo glasbeno ustvarjanje razumljeno kot obrtniško delo. Tako komponiranje kot igranje inštrumentov sta bili predvsem obrtniški spretnosti. Danes avtonomne umetnosti, ki jih opredeljuje predvsem estetska funkcija, jasno ločujemo od obrtniških izdelkov, ki so sicer lahko lepi, a je njihova glavna značilnost uporabnost. Ko se je glasba osvobodila zunanje legitimacije, se je pojavila potreba po trajnejših produktih, ki bi bili primerljivi z drugimi umetniškimi artefakti npr. s slikami, kipi ali z romani in ki bi jih bilo mogoče analitično preučevati. Tako je bil ustvarjen koncept glasbenega dela. Po Lydii Goehr so glavne značilnosti koncepta glasbenega dela naslednje:

a) je edinstvena in zavestno ustvarjena kompozicija; glavni cilj glasbene aktivnosti je proizvesti glasbeno delo,

b) materializira in ohranja se v obliki partiture,

c) kot zaključena forma obstaja že pred svojo izvedbo, pa tudi če izvedbe sploh ni ali če je izvedb več. ${ }^{28}$

Omenjeni koncept danes regulira celotno glasbeno prakso in z njo povezane pojme - biti resen glasbenik pomeni ustvarjati ali poustvarjati glasbena dela. Lydia Goehr govori o konceptualnem imperializmu in trdi, da je bila po letu 1800 celotna glasbena zgodovina rekonstruirana na način, da je ustrezala prevladujočemu konceptu glasbenega dela. ${ }^{29}$

Ko glasba postane striktno intelektualna dejavnost, mora biti cilj izvedbe glasbenih del razkrivanje njihove formalne strukture in skladateljevih idej, ki se skrivajo v njej. Ker je glasbeno delo edinstven in zavesten produkt ustvarjalnih sil skladateljskega genija, mora biti njegova izvedba natančna reprodukcija notnega teksta, v katerem je materializirano. Posledično je prepovedana kakršnakoli improvizacija ali samovoljno okraševanje, ki sta v preteklih obdobjih predstavljala osnovo glasbene izvedbe; izvajalec postane neviden služabnik dela, ki ga mora izvesti z največjo natančnostjo in spoštovanjem. Novo razmerje med skladateljem, delom in izvajalcem se izraža v ideologiji

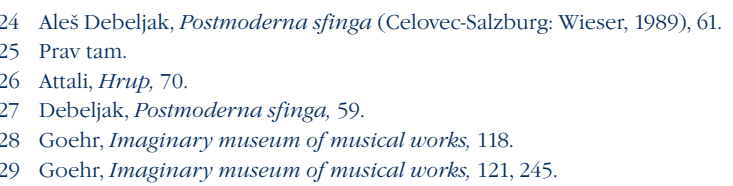


Werktreue (zvestoba delu), to je prepričanje, po katerem so izvajalci in izvedbe del podrejeni delom in njihovim skladateljem. ${ }^{30}$ Ideologijo najustrezneje razloži Wagnerjev citat:

Največja zasluga izvajalca, virtuoza, je čista in popolna reprodukcija skladateljeve misli... Pred nas mora namreč stopiti čisto reproducirano glasbeno delo, nikoli pa moteča individualnost izvajalca. ${ }^{31}$

$\mathrm{V}$ tradiciji zahodne klasične glasbe so romantične virtuoze nadomestili modernistični virtuozi, katerih naloga je bila razumski pristop $\mathrm{k}$ izvedbam oblikovno in harmonsko vse zahtevnejših del modernizma. Ker v center zanimanja stopa glasbeno delo, je najboljša izvedba tista, ki razkrije čim več dela in čim manj izvajalca. V kontekstu modernistične glasbe je izvajalec pogosto razumljen celo kot moteč element, saj njegova osebnost lahko pomeni oviro pri sprejemanju glasbenih del kot avtonomnih objektov. ${ }^{32}$ Telesnost, nujno povezana z izvedbo del, je pogosto razumljena kot nepotreben vizualni dražljaj, ki lahko nastopa kot motnja strukturiranemu poslušanju, nujno potrebnemu za razumevanje kompleksnih modernističnih kompozicij. Če je romantičnemu virtuozu bistvena poudarjena telesnost, pa mora pri modernističnem virtuozu ta ostati kar se da skrita, v ospredje stopa razum. Modernistični virtuoz lastno individualnost podreja glasbenemu delu in skladateljevim idejam, njegovi telesni gibi pa so omejeni izključno na geste, nujno potrebne za ustvarjanje zvoka. ${ }^{33}$

\section{Česa nas je naučila izkušnja akuzmatike}

Težnja po popolni kontroli in izključevanju inštrumentalista, kot vmesnega člena med skladateljem in poslušalcem, je nekatere skladatelje vodila v elektronski studio. Ko je zvok generiran s pomočjo elektronskih naprav, izgubi še zadnje povezave s človeško telesnostjo, ki jim je bil zavezan v okvirih akustične glasbe. Skladbe za magnetofonski trak in elektronsko sintezo zvokov zaznamujeta tehnokratskost in izjemna racionalističnost, rezultat pa so fiksne studijsko producirane skladbe. Posledično glasba postane »izključen privilegij skladatelja«, ${ }^{44}$ hkrati pa je izgubljen fizični stik med glasbenikom in njegovim inštrumentov, ki je stoletja predstavljal temelje glasbene prakse in inovacije. Z izgubo telesne povezave med glasbenikom in inštrumentom pa so izgubljene tudi nekatere bistvene lastnosti, ki sicer zaznamujejo glasbeno prakso - "spontanost, dialog, odkrivanje in skupinska interpretacija«. ${ }^{35}$

Elektronska glasba na ta način nadaljuje v zahodni kulturi in glasbi dolgo prisotno tradicijo ločevanja telesa in razuma in jo deloma celo zaključuje. Obstaja namreč smer, ki je popolnoma izključila človeško prezenco tudi iz koncertnega konteksta - musique

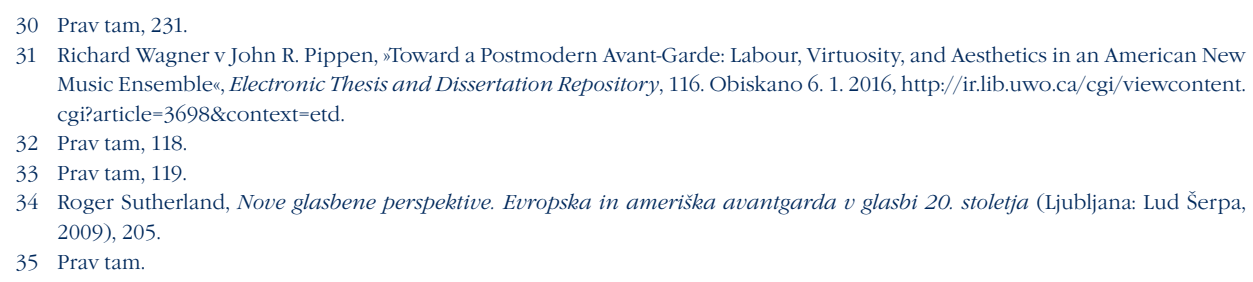


acousmatique oz. akuzmatična glasba. Termin izhaja iz grške besede akusmatikoi, ki "je označevala tiste Pitagorove učence, ki so zaradi boljše koncentracije svojega učitelja poslušali za zaveso in ga torej niso videli«. ${ }^{36}$ Namen takšnega poslušanja je bila slušna koncentracija brez motečih vizualnih dražljajev. Pri akuzmatični glasbi poslušalci ne vidijo oz. ne morejo najti izvora zvoka. S pretrganjem vseh referencialnih zvez so ustvarjeni idealni pogoji za reducirano poslušanje, ${ }^{37}$ to je način poslušanja, pri katerem je vsa pozornost usmerjena na značilnosti in karakteristike zvoka.

Z elektronsko glasbo je zahodna klasična glasba dobila možnost, da dokončno zadosti vrednotam kartezijanskega dualizma in popolnoma izključi človeško telo iz ustvarjalnega konteksta - glasba se je lahko realno vzpostavila kot kristalizacija čistega razuma oz. ideje. A če nas je akuzmatična glasba česa zares naučila, je to najbrž dejstvo, da je človeška prezenca v glasbenem kontekstu še kako pomembna. Razloge za to je potrebno iskati v prepletu glasbene tradicije in sodobne glasbene prakse.

Glasba kot performativna dejavnost je mnogo starejša od konceptov notnega zapisa, skladatelja, glasbenega dela in koncerta. Pravzaprav je zahodna klasična glasba edina, ki takšne koncepte sploh striktno ločuje. Pogled v sodobne popularne zvrsti in v glasbe drugih kultur nam pokaže, da je bistvo glasbene dejavnosti živo izvajanje, pri katerem ima proces muziciranja prednost pred formalno strukturo dela. Glasbena dejavnost je tako rezultat zvočnih, vizualnih in socialnih interakcij. Kot performativna dejavnost je glasba globoko zakoreninjena tudi v kulturnem kapitalu poslušalcev zahodne klasične glasbe in težko je pričakovati, da bodo pripravljeni sprejeti popolno odsotnost človeške prezence, torej živega izvajanja glasbe, v koncertnem kontekstu.

Drugi razlog izhaja iz dejstva, da sodobno kulturo »vsestransko obvladuje vizualno in podoba ${ }^{38}$ Medijski teoretik Marshall McLuhan trdi, da se je pod vplivom razsvetljenstva in znanstvene revolucije naša kultura iz akustično-orientirane preobrazila v vizualno-orientirano. Po Michaelu Benamouju pa prav performativnost predstavlja glavno značilnost postmoderne kulture. ${ }^{39}$ Zato se počutimo udobno z glasbeniki, fiksiranimi na odru pred nami, neprijetno pa, kadar izvora zvoka ne moremo videti ali identificirati. Naša kultura očitno preferira vidne zaznave in tudi če si tega ne priznamo, so ob obisku koncerta vizualne informacije pomembne vsaj toliko kot zvočne. Prek vizualnega stika občinstvo vzpostavlja empatične povezave z izvajalcem (mirroring), hkrati pa mu fizične geste glasbenikov pomagajo predvideti nadaljnji potek zvočnih dogodkov. Kadar je izvajalec odsoten, kot v akuzmatični glasbi, je občinstvo prikrajšano za velik del informacij.

V nasprotju z modernistično ideologijo, ki je želela izvajalca narediti čim bolj neopaznega, da bi se lahko v polnosti izpostavilo glasbeno delo, postmodernizem ponovno odkriva izvajalca, ki ni zgolj medij prenosa glasbenih idej med skladateljem in poslušalcem, pač pa bistveno prispeva $\mathrm{k}$ formaciji in percepciji le-teh. V postmodernizmu so se pojavili nekateri kompozicijski slogi, ki nasprotujejo konceptu glasbenega

36 Gregor Pompe, Novi tokovi v glasbi 20. stoletja (Ljubljana: Znanstvena založba Filozofske fakultete, 2014 ), 213.

37 Christoph Cox in Daniel Warner, Audio culture: readings in modern music (New York, London: Continuum, 2007 ), 66.

38 Fredric Jameson, Kulturni obrat. Izbrani spisi o postmoderni (Ljubljana: Studia humanitatis, 2012 ), 123.

39 Philip Auslander, „Postmodernism and performance«, The Cambridge Companion to Postmodernism (Cambridge: Cambridge University Press., 2004), 99. 
dela, kot ga je definirala Lydia Goehr. Nastala ,dela' ne predpostavljajo podrejenega izvajalca (modernističnega virtuoza), pač pa ga - nasprotno - deloma celo vključujejo v ustvarjalni proces. Gre za odprte oz. nedoločene glasbene forme, ki jih filozofa Umberto Eco in Gilles Deleuze povezujeta s splošnimi karakteristikami sodobne kulture. Če je tradicionalni koncept ,zaprtega dela' zrcalil družbe, ki jim dominirata newtonska fizika in ideja Boga, pa odprte forme izražajo nedeterminiranost kvantne fizike in sveta, ki se je osvobodil teološke dominacije. ${ }^{40}$ Odprta forma v glasbi tako predstavlja izziv modernističnemu dojemanju izvajalca kot podrejenega skladatelji in glasbenemu delu.

\section{Izvajalec v (sodobni) muzikologiji}

Kot je bilo povedan na začetku, zahodno klasičnoglasbeno prakso bistveno opredeljuje razcep na avtorstvo in izvedbo. Od leta 1800 se je izvajalec zahodne klasične glasbe lahko vzpostavil kot romantični virtuoz, virtuozni zvezdnik, ki navdušuje široke množice, ali kot modernistični virtuoz, podrejen izvajalec glasbenih del. Verjetno pa je jasno, da $\mathrm{v}$ realnosti ne moremo najti izvajalcev, ki bi jih lahko definirali kot izključno romantične ali modernistične virtuoze. Termina tako uporabljam kot idealna tipa, ki kljub poimenovanju nista nujno vezana zgolj na specifična zgodovinska obdobja. Po Maxu Webru sociologija za razliko od zgodovine, ki »si prizadeva za vzročno analizo in oceno individualnih, kulturno pomembnih dejanj, tvorb [...] in osebnosti«, tvori »pojme v obliki tipov in išče splošna pravila dogajanja«. ${ }^{41}$ Idealni tip ustvarimo z »enostranskim stopnjevanjem enega ali več gledišč ${ }^{42}$ posledično pa takšna tvorba ne more biti $\mathrm{v}$ celoti prisotna $\mathrm{v}$ resničnosti. Realne tipe ocenjujemo in razvrščamo glede na bližino posameznim idealnim tipom.

Ideali tip romantičnega virtuoza se ni skladal z vse bolj elitistično pozicijo moderne umetnosti in je bil z vidika muzikologije hitro pregnan v območje popularne kulture. Modernistični virtuoz pa kot izvrševalec v partituri zapisanih navodil izvajalec ni bil razumljen kot pomemben člen pri formaciji glasbenega pomena - ta je potekala na eni strani v razumu skladatelja in na drugi strani v razumu poslušalca. Niti romantična niti modernistična virtuoznost tako nista predstavljali predmeta zanimanja muzikološke znanosti, ki se je ukvarjala predvsem s skladatelji in njihovimi deli.

V zadnjih desetletjih pa so se pojavile skupine muzikologov, ki opozarjajo na kompleksno pozicijo glasbenih izvajalcev in na odnos muzikologije do tega vprašanja. Eden tistih, ki svoj raziskovalni fokus obračajo prvenstveno na izvajalca, je britanski muzikolog Daniel Leech-Wilkinson. Po njegovem mnenju je muzikologija pogosto videla svojo edino povezavo $\mathrm{z}$ izvajalci $\mathrm{v}$ dajanju navodil in zapovedi, kako je potrebno neko delo izvesti. Muzikolog $\mathrm{v}$ tem kontekstu nastopa kot nosilec znanja in vedenja, ki si ga je pridobil s poglobljeno analitično in zgodovinsko študijo glasbenih del. V realnosti pa je način, kako je glasba zvenela v konkretni izvedbi, vedno vplival na njeno

40 Cox in Warner, Audio culture, 165.

41 Max Weber, „Temeljni sociološki pojmi«, Kompendij socioloških teorij, Frane Adam in Matevž Tomšič, ur. (Ljubljana: Študentska založba, 2004), 67 .

42 Kurt Blaukopf, Glasba v družbenih spremembah. Temeljne poteze sociologije glasbe (Ljubljana: Studia Humanitatis, 1993 ), 155. 
koncepcijo v muzikologiji. Leech-Wilkinson prek proučevanj posnetkov dokazuje, da se je s spreminjanjem izvajalske prakse vzporedno spreminjal tudi način pisanja o glasbi. ${ }^{43}$ Trdi, da nas izvajalci lahko naučijo stvari, ki so prav tako zanimive in resnične kot tiste, do katerih pripeljejo muzikološke analize.

Kot primer si oglejmo Leech-Wilkinsonovo analizo sprememb v znanstvenem pisanju o Schubertovih samospevih, ki so jih povzročile predhodne spremembe v njihovi izvajalski interpretaciji. Na predvojnih posnetkih Schubertovi samospevi zvenijo kot enostavne pesmi, v katerih glasba ilustrira površinsko vsebino besedila - gre za preprosto in direktno ekspresijo v besedilu očitno prisotnih emocij. Muzikološki komentarji samospevov se osredotočajo predvsem na pravilno in konstantno razmerje med klavirjem in vokalom; vsebinsko se dogaja natančno to, kar opisujejo besede. Schubert je v muzikoloških zapisih iz tega obdobja opisovan kot sramežljiv in naiven skladatelj, ki z melodičnimi postopi natančno opisuje besedilo skladbe. Po drugi svetovni vojni pa se je pod vplivom splošne družbene klime, razočaranja nad človeško naravo in doživetjem vojnih grozot način izvajanja samospevov spremenil. Izvedbe Schubertovih samospevov naenkrat zaznamujejo "eksplozivni sforzandi, močne konsonance, občasni zdrsi med posameznimi tonskimi višinami «, ${ }^{44} \mathrm{v}$ katerih se zrcali vpliv Freudove teorije nezavednega. Vendar pa mora preteči še nekaj desetletij, preden se podoba Schuberta spremeni tudi v muzikološki literaturi. Šele v sedemdesetih letih lahko najdemo pisne interpretacije Schubertovih samospevov, ki glasbo opisujejo v kontekstu drame in notranjega boja protagonistov. Predvidevamo torej lahko, da poglobljena psihološka interpretacija Schubertovih samospevov ne bi bila mogoče brez predhodne spremembe v izvajalski praksi. Posledično lahko trdimo, da je vpliv izvedbenih tradicij na muzikologijo intenzivnejši kot obratni vpliv. 45

Za razliko od tradicionalnega zahodnega dojemanja glasbe, ki kot bistvo glasbene prakse razume ustvarjanje notiranih glasbenih del, se za večino izvajalcev in tudi za nekatere muzikologe glasba dogaja predvsem v performativnem kontekstu. Leech-Wilkinson navaja več razlogov, ki zagovarjajo posvečanje izvajalcem in njihovemu delu v kontekstu muzikološke znanosti. Prvi in najočitnejši razlog izhaja iz dejstva, da do glasbe dejansko ne moremo dostopati drugače, kot prek izvedbe. Tudi, kadar beremo partituro, jo izvajamo v svojih mislih. Kadar si zamislimo določeno delo, si ne zamislimo njegove partiture, pač pa njegovo zvočno realizacijo - izvedbo, ki pa je vedno podvržena trenutnim izvedbenim tradicijam. Izvedba torej nepovratno oblikuje in zaznamuje našo percepcijo in razumevanje glasbenih del. ${ }^{46}$ Po Leech-Wilkinsonu glasbeno delo ne more obstajati kot objekt, pač pa zgolj kot proces. Preostali razlogi so povezani z razvojem snemalnih tehnologij in s posledično sočasno dostopnostjo več različnih izvedb istega dela. Njihova raznolikost dokazuje, da obstaja mnogo interpretacij istega notnega teksta in da glasbeno delo torej ne more obstajati kot fiksna objektivna entiteta. Posledično tudi ne moremo trditi, da obstaja neka idealna izvedba dela, ki bi bila

43 Daniel Leech-Wilkinson, »Musicology and Performance«, 791. Obiskano 10. 3. 2016, http://www.rilm.org/historiography/leech. pdf.

44 Prav tam, 800.

45 Prav tam, 800-803.

46 Leech-Wilkinson, "The changing sound of music«, 2'23. 
točno taka, kot si jo je zamislil skladatelj. Takšno prepričanje se sklada tudi s postmodernistično teorijo pluralnosti resnic, ki jo zagovarja francoski teoretik postmodernizma Jean-François Lyotard. Več izvedb istega dela je lahko enako kompetentnih. ${ }^{47}$

Vse več sodobnih muzikoloških raziskav se osredotoča tudi na izvajalčeve vizualne signale in njihovim vplivom na poslušalca. Teresa Vila Verde poudarja, da živa izvedba glasbe nikoli ni samo zvočni, pač pa vedno tudi vizualni dogodek. ${ }^{48}$ Posledično bi bilo po njenem potrebno vizualno dimenzijo glasbenega dogodka iz omejenega nabora glasbenih gest razširiti na celoten oder, torej vključiti gledališkost v glasbeno ustvarjanje. Eden od postmodernih postopkov, ki jih v tem kontekstu predlaga Vila Verde, je uporaba koreografije. John Pippen je takšno uporabo analiziral na primeru ameriške skupine eighth blackbird, ki se posveča predvsem izvajanju glasbe iz obdobja modernizma in postmodernizma. Uporaba koreografije pomeni jasen odmik od modernističnih idealov zakrivanja izvajalca, saj poudarja predvsem vizualni aspekt koncertnega nastopa. S pomočjo koreografije želi eighth blackbird približati sodobno glasbo širšemu spektru poslušalcev. Z dodajanjem vizualnih elementov v koncertni ritual, torej prakso, ki se je v obdobju modernizma usmerila v striktni intelektualizem, želijo glasbeniki ustvariti izkušnjo, razumljivo sodobnemu občinstvu, ki ga opredeljuje predvsem vizualnost kulture. Njihovi premiki po odru in telesne geste služijo kot ilustracija glasbenega dogajanja oz. kot vizualna reprezentacija glasbenih odnosov. Uporaba vizualnih stimulansov predstavlja »izziv modernističnim vrednotam interiornosti in avtonomije, značilnim za tradicijo klasične glasbene izvedbe«. ${ }^{49} \mathrm{~V}$ glasbenem kontekstu je vizualnost pogosto tretirana kot del postmoderne površinskosti, v kontrastu z modernističnim poudarjanjem notranje subjektivnosti. ${ }^{50}$ Številni glasbeni kritiki so tako izrazili močno nasprotovanje takšnim pristopom - Mark Swed je uporabo koreografije označil za "nadležno in "way too cute (vse preveč ljubko) «. ${ }^{11}$ Jasno je, da se uporaba koreografije ne sklada s še vedno prevladujočim hierarhičnim modelom, po katerem je glasbeno delo pomembnejše od izvajalca. Pippen pa je prek pogovorov s člani skupine eighth blackbird prišel do zanimivega zaključka. Čeprav je koreografija uporabljena predvsem z namenom zadostiti postmodernističnim idealom dostopnosti, v resnici izhaja iz modernističnih principov. Glasbeniki sami sebe dojemajo kot podrejene glasbenim delom in tako poudarjajo, da koreografija vedno nastopa $\mathrm{v}$ »interesu glasbenega dela«, da torej zgolj poudarja ideje, ki so »že prisotne v glasbi«. ${ }^{2}$ Uporaba koreografije je torej za člane skupine eighth blackbird legitimna zgolj v okvirih, v katerih prinaša dodatno razlago glasbenega poteka - dokler izhaja »iz glasbene resnice« in »iz glasbe same ${ }^{53}$ Celo, ko je izvajalec izpostavljen in nedvomno prisoten, torej ostaja podrejen idejam skladatelja in glasbenega dela.

47 Prav tam, 2-38-40.

48 Teresa Vila-Verde, "Assessing the importance of visual/theatrical features in the perception of music by an audience, using sociological tools«, International Symposium on Performance Science, 148. Obiskano 15. 5. 2016, http://www.performancescience. org/ISPS2007/Proceedings/Rows/28VilaVerde.pdf.

49 Prav tam, 131.

50 Prav tam.

51 Swed v: prav tam, 125.

52 Prav tam, 128.

53 Prav tam. 


\section{Postmodernizem - teoretsko ozadje}

Uveljavitev termina postmodernizem postavljamo v šestdeseta leta prejšnjega stoletja, kot umetnostna smer pa se vzpostavi v trenutku, ko modernistične forme, ki jih je Adorno videl kot "zadnji branik pred neznosno banalnostjo in skomercializiranostjo družb «, ${ }^{54}$ zasedejo institucionalizirani prostor galerij, koncertnih dvoran in muzejev ter se na ta način iz nekdaj subverzivnih in bojevitih stilov preobrazijo v etablirano meščansko kulturo. ${ }^{55}$ Kot osnovno determinanto postmodernih slogov Fredric Jameson navaja smrt subjekta oz. avtonomne individualne monade. V visokem modernizmu sta jedrna družina kot osnovna družbena celica in tekmovalnost klasičnega kapitalizma predpostavljala izrazito individualiziran subjekt, ki se je v umetnosti izražal kot fetišizacija novosti in unikatnega sloga. Korporativni kapitalizem pa s porastom birokratizacije povzroči zlom visokomodernistične ideologije individualne osebnosti, kar na umetnostnem področju prinese konec inovacije in obračanje v preteklost. ${ }^{56}$ Jameson kot reprezentativni postmoderni umetnostni postopek tako navaja pastiš, ki nadomesti modernistično parodijo. Pastiš je "prazna ironija in "nevtralna praksa takšne mimikrije, brez skrivne motivacije parodije, brez satiričnega vzgiba, brez smeha, brez vsaj latentnega občutka, da nekje obstaja nekaj normalnega, nekaj, v primerjavi s čimer je to, kar imitiramo, komično «.57

Bistvo, ki ga Jameson ponuja v svojih analizah, pa je razumevanje, da pri postmodernizmu pravzaprav ne gre zgolj za specifičen umetnostni slog, pač pa za kulturno dominanto. Pri tem se nasloni na osnovno tezo dela Pozni kapitalizem, v kateri avtor Ernest Mandel razvoj kapitalizma opiše v treh temeljnih momentih: tržni kapitalizem, monopolna stopnja oz. stopnja imperializma in postindustrijski kapitalizem - za slednjega Jameson predlaga poimenovanje multinacionalni oz. potrošniški kapitalizem, asociira pa ga s sintagmama družba medijev in družba spektakla. Mandelovi strukturi je kompatibilna Jamesonova tripartitna shema realizem - modernizem - postmodernizem. ${ }^{58}$ Za Jamesona je postmodernizem predvsem "poskus teoretizacije specifične logike kulturne produkcije «59 multinacionalnega kapitalzma, ki ga zaznamuje ekspanzija kapitala na do tedaj avtonomna področja. Kot rezultat tovrstne ekspanzije nastopi dediferenciacija predhodno ločenih družbenih sistemov - tržna logika neustavljivo prodira na področje kulture, po drugi strani pa je vse, »tudi blagovna produkcija in spekulativne finance, postalo kulturno«. ${ }^{60}$ Tradicionalna specifičnost estetskega in kulture je zabrisana, saj se kultura razširi po vsem družbenem polju. ${ }^{61}$ Aleš Debeljak estetizacijo vsakdanje izkušnje vidi predvsem kot posledico propadlega oz. le delno uresničenega projekta zgodovinskih avantgard - konstruktivizma, futurizma, nadrealizma

\footnotetext{
54 Primož Krašovec, „Kultura in finančni kapitalizem v pozni postmoderni (Spremna študija)«, Kulturni obrat. Izbrani spisi o postmoderni, 1983-1998 (Ljubljana: Studia humanitatis, 2012), 233.

55 Prav tam; Jameson, Kulturni obrat, 8.

56 Jameson, Kulturni obrat, 13.

57 Prav tam.

58 Fredric Jameson, Postmodernizem (Ljubljana: Društvo za teoretsko psihoanalizo, 2001), 38.

59 Jameson, Kulturni obrat, 47.

60 Prav tam, 93.

61 Prav tam, 136.
} 
in dadaizma. Avantgarde so zavračale ravno tisto opozicijo med umetnostjo in vsakdanjim življenjem, ki je predstavljala temelj legitimacije romantične in modernistične umetnosti kot avtonomnega področja. S prevpraševanjem ločnice med umetnostjo in vsakdanjim življenjem so si avantgarde prizadevale za osvoboditev umetnosti od omejitev žanrov, oblik, materialov in strok ter njeno integracijo v vsakdanje življenje. ${ }^{62}$ Posledično so zavračale samo institucijo umetnosti, torej referenčni okvir, "znotraj katerega poteka ritmično menjavanje $\log 0$ «. ${ }^{63}$

Do prenosa avtonomne umetnosti v tkivo vsakdanjega življenja je zares prišlo, toda le v izredno razvodeneli enačici, in sicer skozi estetiziranje vsakdanje izkušnje. Umanjkala pa je odgovarjajoča družbena preobrazba. Slednje ni bilo mogoče uresničiti zaradi krepitve korporativnega sponzorstva posredniških ustanov, ki je pripeljalo v vsepovsod prisotno privatiziranje in komercializacijo meščanske javne sfere. Korporativno gospostvo nad proizvodnjo, distribucijo in recepcijo umetnosti je skoraj povsem izkoreninilo razliko med javnim in zasebnim iz moderne tradicije ter s tem spremenilo muzeje, založniške hiše, galerije, univerze in druge ustanove v orodja perifernega političnega nadzora. ${ }^{64}$

Prav v kontekstu medsebojnega prepletanja vsakdanjega življenja in umetnosti je potrebno razumeti tudi Jamesonovo interpretacijo Heglovega ,konca umetnosti‘. Pri tem se avtor osredotoči na dva od Heglovih številnih trojnih modelov - na model gibanja duha, ki na poti do absolutnosti prečka tri stopnje: religijo, umetnost in filozofijo, znotraj tega pa na model napredka umetnosti od simbolne in klasične do romantične. Romantika naj bi prinesla konec umetnosti in primat filozofije kot "zgodovinskega samozavedanja absolutne sedanjosti«. ${ }^{65} \mathrm{Na}$ prvi pogled so Heglova predvidevanja katastrofalno napačna, saj ravno z romantiko in modernizmom, ki ji sledi, umetnost doseže enega svojih največjih razcvetov, hkrati pa Hegel in nemški idealisti predstavljajo vrhunec, a tudi zaključek velikih in absolutnih filozofskih sistemov, katerih avtoriteto v modernizmu spodkopavata razvoj naravoslovnih ved in vse intenzivnejše kritike »abstrakcije in instrumentalnega uma, ki jih je navdihovalo izkustvo industrijskega mesta ${ }^{66}{ }^{66}$ Modernistična umetnost se v tem kontekstu formira kot alternativna pot do Absolutnega in kot "najvišja oblika v kateri se resnica prebija v bivanje ${ }^{67}$ A Jameson v koncu romantike kljub temu vidi nekaj, kar bi lahko imenovali ,konec umetnosti ${ }^{‘}$ - da bi ta konec prepoznali, pa moramo vključiti Kantovi kategoriji Lepega in Sublimnega in predpostaviti, da je bistvo modernistične umetnosti doseganje Sublimnega, torej nekakšna transestetika, ki umetnost vidi kot sredstvo in način približanja Absolutnemu. ${ }^{6}$ Heglov ,konec umetnosti‘ je tako konec umetnosti kot Lepega, ki pa ga ne nadomesti filozofija, pač pa Sublimno. Lepo še obstaja, a zgolj kot okrasje, ki pa nima dostopa do resnice in Absolutnega - Peter Bürger vztrajanje Lepega identificira kot obstoj dekorativne umetniške produkcije. Konec modernizma Jameson razume kot »razpustitev

62 Debeljak, Na ruševinah modernosti, 142.

63 Prav tam, 145.

64 Prav tam, xix

65 Jameson, Kulturni obrat, 97.

66 Prav tam, 104.

67 Prav tam.

68 Prav tam. 
razmerja med umetnostjo in Absolutom «. ${ }^{69}$ Ta drugi ,konec umetnosti‘, ki je konec umetnosti kot Sublimnega, zaznamuje izginjanje velikih avtorjev (J. Joyce, M. Proust, Le Corbusier, L. Mies van der Rohe, A. Schönberg) in njihovo nadomeščanje z velikimi teoretiki (J. Baudrillard, J. Lacan, R. Barthes, J. Derrida, G. Deleuze). Prav pojav Teorije kot nečesa, »kar je bilo najprej le dodatek tradicionalni literaturi, nato pa se je razširilo po disciplinah vse od filozofije do antropologije in od lingvistike do sociologije« razume Jameson v smislu »heglovskega preseganja umetnosti s filozofijo ${ }^{70}{ }^{70}$ Teorija izhaja iz estetike, a jo hkrati tudi konstituira. V postmodernizmu torej Teorija prevzame funkcijo Sublimnega, medtem ko umetnost »opusti iskanje Absoluta ali resnice in se redefinira kot izvor čistega ugodja in zadovoljitve «. ${ }^{71}$ Umetnost v postmodernizmu torej zaznamuje nazadovanje k starejšemu kulinaričnemu in dekorativnemu statusu.

Bistvo postmoderne umetnosti torej ni v umetnostnih postopkih - ti so pravzaprav v veliki meri prevzeti iz predhodnih obdobij. Specifika postmoderne umetnosti izhaja iz spremembe njenega mesta $v$ kulturi - iz nazadovanja $v$ dekorativno funkcijo, iz izgube avtonomnosti ter vpetosti v tržna razmerja potrošniškega kapitalizma. Takšna umetnost ni več sposobna zavzeti kritične distance do sistema, pač pa le reproducira obstoječa razmerja in s tem krepi logiko potrošniškega kapitalizma. ${ }^{72}$

Prispevek Fredrica Jamesona k razumevanja postmodernizma in postmoderne umetnosti je dvojen. Z interpretacijo Heglovega ,konca umetnosti‘ nam pomaga razumeti izgubo subverzivnega avtonomnega statusa, ki ga je kot pot k Absolutnemu in iskalka resnice uživala modernistična umetnost, ter posledično nazadovanje postmoderne umetnosti v funkcijo dekoracije. Z razumevanjem postmodernizma kot kulturne dominante oz. kulturne logike poznega kapitalizma pa razloži dediferenciacijo posameznih družbenih področij, ki rezultira tako v estetizaciji vsakdanjega življenja kot tudi v izgubi specifičnosti estetske izkušnje, hkrati pa omogoča prenos izvorno tržnih strategij v polje umetnostne produkcije. V tem kontekstu velja razumeti tudi pogosto opevano postmoderno brisanje ločnice med visoko umetnostjo in popularno kulturo.

\section{Koncertni ritual in njegove spremembe $\mathrm{v}$ postmodernizmu}

Glasbeni tekst zaznamujejo kompozicijske zakonitosti in inherentne glasbene značilnosti obdobja, v katerem je bil ustvarjen. Med strokovnjaki pa še vedno ni prišlo do konsenza o tem, do kolikšne mere zgodovinski kontekst določa tudi posamezno izvedbo. Glasbeni teoretik Heinrich Schenker je tako na prehodu iz 19. v 20. stoletje trdil, da glasbena tekstura sama po sebi nakazuje ustrezno interpretacijo in da so nepotrebne celo dinamične oznake v notnem tekstu. ${ }^{73}$ Če tonske višine, ritem in harmonija ter njihova medsebojna razmerja natančno določajo interpretacijo, mora biti ta enaka, ne glede na družbene okoliščine izvedbe. Popolnoma nasprotno pozicijo zavzema

69 Prav tam, 105

70 Prav tam, 106

71 Prav tam, 107

72 Prav tam, 29.

73 Mine Doğantan-Dack, "Artistic research in classical music performance: Truth and politics«, Parse journal \#1: Judgement, 33. Obiskano 2. 3. 2016, http://parsejournal.com/issue/1/. 
sodobna violinistka Patricija Kopačinska, ki izvedbo definira kot osebno srečanje med interpretom, glasbenim delom, skladateljem in družbenim kontekstom. Interpretacija klasičnega koncertnega repertoarja mora tako nujno vključevati vplive sodobnosti, saj se le na ta način lahko izognemo brezsmiselnemu ponavljanju vedno enakih izvedb. Za Kopačinsko je vsaka izvedba fenomen sui generis, njene značilnosti pa so pogojene tudi s prostorsko akustiko posameznih dvoran ter z lokalnim kulturnim kontekstom: »V Amsterdamu lahko Mozarta igram bolj svobodno, kot v Salzburgu. Spet drugače pa v nerealnih belih nočeh finskega Khuma ${ }^{74}$ Gre za izrazito postmoderen pristop, ki pa se deloma navezuje na romantični interpretacijski ideal, ki ga Gregor Pompe poimenuje aktualizirajoči tip interpretacije. Ta starejše notne tekste skuša "prilagoditi glasbenim danostim in okusu sočasnosti ${ }^{75}$ Poleg tega Pompe ločuje še tradicionalistično interpretacijo, ki »slepo sledi interpretacijskemu izročilu in se ne sprašuje ne o zvestobi preteklosti ne o modni aktualnosti ${ }^{76}$ in najmlajši interpretacijski pristop - historično izvajalsko prakso, katerega glavni cilj je avtentičnosti izvedbe. A zatakne se že pri sami definiciji avtentičnosti - naj bi ta "prinesla interpretacijo skladbe, kakšno si je želel skladatelj ali naj bi se čim bolj približala izvedbi, kakršna je bila značilna za čas nastanka del«? ${ }^{77}$ Za Kopačinsko je resnično ,historična' izvedba tista, ki v današnjem občinstvu vzbudi enaka čustva, kot jih je ob prvi izvedbi. Če je bilo Vivaldijevo občinstvo osupnjeno spričo njegove drzne virtuoznosti, takšne osuplosti danes zagotovo ne bomo dosegli z uporabo enakih sredstev. ${ }^{78}$ Že dejstvo, da obstajajo različne interpretacijske tradicije in nešteto različnih interpretacij, napeljujejo na domnevo, da vsako izvedbo zahodne klasične glasbe bistveno zaznamujejo tri determinante: a) notni tekst, katerega preciznost je odvisna od obdobja, v katerem je bil napisan in izdan, b) zgodovinski izvedbeni kontekst, ki določa preferiran tip interpretacije in c) osebnost izvajalca, od katere je odvisno, koliko se bo izvajalec podredil notnemu tekstu in družbeno preferiranemu tipu interpretacije.

Ne glede na to, kateri tip interpretacije oz. katero kombinacijo tipov izvajalec izbere, pa ga vedno determinira sama struktura koncertnega rituala. Klasični koncert, kakršnega poznamo danes, se je razvijal v obdobju romantike in modernizma ter ga posledično opredeljujejo splošne in glasbene vrednote teh obdobij. Poleg tega pa je koncertna praksa ohranila tudi nekatere povezave z zgodnjo obredno funkcijo, ko je bila glasba striktno ločena od vsakodnevne rutine in običajnosti. ${ }^{79}$ Nekateri teoretiki, npr. Stephen Cortell, tako opisujejo klasični koncert kot serijo ritualnih praks, ki vzpostavljajo kontrast med koncertom in vsakodnevno življenjsko rutino. Vse, od nakupa vstopnic in posebne tišine $\mathrm{v}$ dvorani do uvodnega aplavza, prispeva k tvorbi občutka ritualnosti - tako za nastopajoče kot za poslušalce. John Pippen po Cortellu in antropologu Victorju Turnerju ločuje tri faze rituala: preliminalno, liminalno in postliminalno. Preliminalna faza predstavlja simbolično ločitev rituala od vsakdanjega

74 Patricija Kopačinska, »My kitchen«. Obiskano 15. 5. 2016, http://patriciakopatchinskaja.com/mykitchen.html.

75 Gregor Pompe, „'Modernost' in historična izvajalska praksa«. Obiskano 15. 5. 2016, http://www.sigic.si/odzven/modernost-inhistoricna-izvajalska-praksa.

76 Prav tam.

77 Prav tam.

78 Kopačinska, »My kitchen«.

79 Goehr, Imaginary museum of musical works, 157. 
Življenja. Običajno se dogaja v preddverju koncertne dvorane, ko občinstvo še ne vidi izvajalcev. Liminalna oz. osrednja faza koncertnega rituala je povezana z dvema temeljnima konceptoma glasbenega modernizma: konceptom dela in strukturiranim poslušanjem. V tej fazi se običajne socialne vloge povsem podredijo osrednjima vlogama izvajalca oz. poslušalca. Postliminalno oz. zaključno fazo koncerta predstavljata končni aplavz in priklon nastopajočih, s katerim je aplavz formalno sprejet, ter njihov odhod iz odra. Namen zaključne faze je vrniti udeležence nazaj v vsakdanje življenje in socialne vloge. ${ }^{80}$ Tako oblikovan ritual v kombinaciji s fizično ločenostjo koncertnih dvoran iz okoliškega konteksta (običajno gre za "prostore znotraj prostorov « ${ }^{81}$ ) predstavlja kontekst, v katerem lahko dojemamo glasbeno delo kot avtonomen umetniški artefakt. ${ }^{82}$

Pri koncertu klasične glasbe gre torej običajno za kombinacijo kanoniziranih glasbenih del, ki so bila napisana v obdobjih klasicizma, romantike in modernizma, ter koncertnega rituala, ki izraža elitistične težnje 19. in 20. stoletja. Kako lahko takšna kombinacija nagovori postmoderno občinstvo? John Pippen je v iskanju morebitnih postmodernih značilnosti sodobnega klasičnega koncerta analiziral koncerte ameriške skupine eighth blackbird. Pippen navaja številne prijeme, ki zadostujejo postmodernim težnjam po dostopnosti in približanju klasične glasbe širšemu občinstvu - poleg že omenjene uporabe koreografije tudi organiziranje pred- in pokoncertnih pogovorov z ustvarjalci in strokovnjaki ter izvedba koncertov na prostem. Manj formalno vzdušje želijo glasbeniki poudariti tudi z uporabo sproščenih koncertnih oblačil. Tradicionalno so bila črna oblačila glasbenikov namenjena skrivanju njihove individualnosti, saj le-ta ni smela motiti prezentacije glasbenega dela. Uporaba barvnih in manj formalnih oblačil pa torej nakazuje na dve težnji: poudarjanje lastne identitete in razbijanje stereotipov o formaliziranosti klasičnih koncertnih dogodkov. ${ }^{83}$ Kljub temu pa Pippen zaključuje z ugotovitvijo, da tovrstne postmoderne strategije predstavljajo zgolj okvir koncertnim ritualom, ki v svojem notranjem bistvu ostajajo zavezani modernistični logiki. ${ }^{84}$

Odgovor na vprašanje - ,Ali je klasični koncertni ritual lahko postmoderen?" - mora biti torej nikalen. Čeprav je bila glasbena kompozicija v obdobjih romantike, modernizma in postmodernizma podvržena radikalnim spremembam, pa je po drugi strani koncertni ritual ves čas ostajal relativno nespremenjen. Mine Doğantan-Dack razloge za to vidi predvsem $\mathrm{v}$ globoko zakoreninjeni ideologiji glasbenega dela, ki funkcijo klasičnega koncerta vidi predvsem v prenosu skladateljevih idej poslušalcem. ${ }^{85}$ Tudi kadar poslušamo dela, ki so prinesla vprašanje o samem ontološkem bistvu glasbe, kot je npr. sklada Johna Cagea 4:33, lahko še vedno jasno prepoznavamo tradicionalne kategorije, kot so koncert, koncertna dvorana, skladatelj, izvajalec in publika. Vsi materialni izzivi, ki jim je bila podvržena glasbena sintaksa (emancipacija disonance, zavrnitev tonalnosti, nove forme in inštrumenti), torej niso prinesli nikakršnih formalnih sprememb v odnosu med skladateljem, notiranim glasbenim delom in izvajalcem.

80 Pippen, „Toward a Postmodern Avant-Garde«, 184-190.

81 Prav tam, 133

82 Prav tam.

83 Pippen, "Toward a postmodern avant-garde«, 89, 92, 165,

84 Prav tam, 196

85 Doğantan-Dack, »Artistic research in classical music performance«, 32. 
Koncertna dvorana nedvomno ostaja ideološki prostor, ki implicira koncepte kot sta avtonomija glasbe in intelektualizem.

\section{Poskus definicije postmoderne virtuoznosti}

Na pozicijo izvajalca klasične glasbe bistveno vplivata splošno dojemanje umetnosti in njene značilnosti v specifični zgodovinski dobi. Poskus definicije postmodernega virtuoza bo torej predvsem poskus poiskati povezave med postmodernizmom kot kulturno logiko poznega kapitalizma in spremembami v poziciji izvajalca klasične glasbe v postmoderni. Po Fredricu Jamesonu postmoderno umetnost zaznamujeta izguba avtonomnosti, ki nastopi kot posledica estetizacije vsakdanjega življenja ter njeno nazadovanje v funkcijo dekorativnega. Klasična glasba mora danes na trgu tekmovati s številnimi oblikami umetnostne in zabavne produkcije in si posledično ne more več privoščiti elitizma, ki jo je iz takšnih ali drugačnih razlogov zaznamoval v preteklih obdobjih. V povezavi z anti-elitizmom postmoderne klasičnoglasbene scene John Pippen uvede koncept friendly virtuosity (prijateljska virtuoznost), ki ga definira kot »utelešenje nasprotij med postfordistično postmodernostjo in vrednotami klasične glasbe«. ${ }^{86}$ Bistvena značilnost prijateljske virtuoznosti je želja po ponovnem približanju klasične glasbe širšemu občinstvu, za doseganje tega pa glasbeniki uporabljajo promocijske strategije, ki so bile do pred kratkim povezane s profitnimi korporacijami. Za tovrstno obravnavanje izdelkov in oseb sociolog Adam Arvidsson uporablja koncept branding. ${ }^{87} \mathrm{~V}$ postmodernizmu $\mathrm{v}$ center glasbene prakse torej ponovno stopa identiteta posameznega izvajalca ali skupine izvajalcev in sicer kot znamka (brand) - ta postaja pomembnejša od produkta samega. Po Jeanu Baudrillardu današnje blago nima več materialne, pač pa predvsem znakovno vrednost ${ }^{88}$ in tudi sodobni izvajalec klasične glasbe obstaja predvsem kot znamka.

Klasični koncert danes tako ni več zgolj dogodek, na katerem se predstavljajo izvajalci (kot pri romantičnem virtuozu) ali glasbena dela (kot v primeru modernističnih virtuozov), pač pa jih glasbeniki dojemajo tudi kot priložnost za trženje lastne blagovne znamke. ${ }^{89}$ Aleš Debeljak opozarja na sodobno zlitje družbenih vlog umetnika in poslovneža ter na »incestuozni stik kapitala in umetnosti, ki je zbujal strah v obdobju romantike in posmeh v modernizmu «. ${ }^{90}$ Podobno Primož Krašovec ugotavlja, da je nova kultura predvsem "podjetniška kultura«.91

Svoje ,prijateljskosti pa izvajalci ne izkazujejo zgolj na koncertnem odru. Tradicionalna virtuoznost (tako romantična kot modernistična) je bila usmerjena v perfekcijo koncertnih nastopov, medtem ko je moralo ostati trdo delo, potrebno za njihovo doseganje, skrito. Nasprotno pa postmoderni izvajalci s publiko delijo tudi pripravo na koncerte in druge izkušnje zunaj koncertnih dvoran - za takšno aktivnost so zelo primerni

86 Pippen, "Towards a postmodern avant-garde«, 18.

87 Slovenska ustreznica znamčenje obstaja kot marketinški, ne pa tudi kot sociološki pojem - termin zato uporabljam v originalni obliki; prav tam, 50 .

88 Pompe, Novi tokovi, 239.

89 Prav tam, 56.

90 Debeljak, Na ruševinah modernosti, 188.

91 Krašovec, »Kultura in finančni kapitalizem v pozni postmoderni«, 246. 
internetni portali kakršna sta Facebook in YouTube..$^{22}$ Objavljanje poročil in posnetkov vaj bistveno vpliva na približanje izvajalcev in njihovega dela. Če sta tako romantični kot modernistični virtuoz gradila podobo, ki je do občinstva zavzemala določeno mero distance in vzvišenosti (na kar nakazuje tudi prostorska separacija nastopajočih in občinstva $\mathrm{v}$ modernističnem koncertnem ritualu), pa postmoderni virtuoz izraža tendenco po približanju publiki - tako v koncertnem kontekstu kot tudi izven njega.

\section{Zaključek}

Cilj raziskave je bil potrditi obstoj idealnega tipa, ki bi ga poimenovali postmoderni virtuoz, in opredelitev njegovih karakteristik. Izkazalo pa se je, da takšen domnevno obstoječi tip jasno zrcali značilnosti dobe, ki ga oblikuje. Pri sodobnem izvajalcu klasične glasbe namreč ni moč prepoznati svojevrstnih lastnosti, ki bi jih lahko uporabili za definicijo postmodernega virtuoza kot idealnega tipa. Skladno s splošnimi lastnostmi postmoderne postmoderni virtuoz tvori nekakšen kolaž oz. palimpsest ${ }^{93}$ lastnosti prej obstoječih tipov. Prepoznamo lahko oglaševanje sodobnih glasbenikov kot romantičnih virtuozov, ki posedujejo nadčloveške glasbene sposobnosti, ki so pripravljeni presegati zvrstne meje in zabavati občinstvo, a hkrati težijo k čim zvestejšim interpretacijam glasbenih tekstov. ${ }^{94}$ Povedali pa smo, da sta romantični in modernistični virtuoz idealna tipa, ki v realnosti ne obstajata, in da realne tipe vrednotimo glede na to, koliko se približajo določenemu idealnemu tipu. Torej so izvajalci že v obdobjih pred postmoderno lahko kombinirali lastnosti obeh idealnih tipov. Kaj torej idealni tip postmodernega virtuoza sploh ločuje od prej obstoječih realnih tipov? Gre za kombinacijo lastnosti, ki vse po vrsti izhajajo iz osnovne determinante umetnosti v postmoderni, torej njene vpetosti v kapitalistični tržni sistem. Kot blago mora klasična glasba na sodobnem trgu tekmovati z drugimi oblikami umetnostne in zabavne produkcije in si posledično ne more več privoščiti elitizma, ki jo je zaznamoval v obdobju modernizma. Postmoderni virtuoz tako nastopa in se trži kot znamka (brand), njegov cilj pa se je čim bolj približati širokim množicam poslušalcev (antielitizem, friendly virtuosity/ prijateljska virtuoznost).

Zahodno klasičnoglasbeno prakso v obdobju postmoderne zaznamujejo številna nasprotja. Na eni strani se še vedno vzpostavlja kot elitistični fenomen (dediščina legitimacije s strani cerkve in dvorov ter modernistične intelektualne naravnanosti) in prek ohranjanja tradicionalne strukture koncertnega rituala prispeva k dojemanju glasbe kot striktno razumske dejavnosti, ki ji dominira koncept glasbenega dela. Kot taka navidezno zavrača sodelovanje v kulturni industriji, saj naj bi le tako lahko ohranila avtonomijo in ,kritično negativnost' (Adorno). Po drugi strani pa si klasični glasbeniki elitistične pozicije ne morejo več privoščiti, saj na trgu tekmujejo s številnimi drugimi

92 Pippen, "Towardsa postmodern avant-garde«, 101.

93 Aleš Debeljak razliko med modernizmom in postmodernizmom vidi kot razliko med kolažem in palimpsestom. Če so za kolaž "kot privilegirano metodo modernizma značilne jasno ohranjene in zato razvidne karakteristike različnih izoliranih, a med seboj povezanih tujih in avtorskih elementov, pa pri palimpsestnem prosevanju različnih plasti ni več mogoče reči, kaj je avtorsko in kaj prisvojeno«; Debeljak, Postmoderna sfinga, 104.

94 Pippen, "Towars a postmodern avant-garde«, 64. 
oblikami umetnostne in zabavne produkcije. Poleg tega postmoderna klasičnoglasbena praksa pod vplivi splošnega poblagovljenja in performativne naravnanosti postmoderne družbe izraža težnje po široki dostopnosti in ponovnem vključevanju telesnosti. Romantične, modernistične in postmoderne težnje se vedno znova znajdejo v ostrem nasprotju, izvajalci pa morajo na individualni ravni reševati strukturne napetosti družbe (Beck). Celotno breme uspeha, »tako uspeha posameznega glasbenika kot uspeha klasične glasbe v celoti ${ }^{95}$ pade na ramena posameznika. Naloga postmodernega virtuoza je, da nasprotja uspešno razreši in poišče ustrezno pozicijo med telesom in razumom.

\section{Bibliografija}

Adorno, Theodor W. Uvod v sociologijo glasbe. Ljubljana: Državna založba Slovenije, 1986.

Althusser, Louis et al. Ideologija in estetski učinek. Ljubljana: Cankarjeva založba, 1980.

Arvidsson, Adam. Brands: Meaning and value in media culture. London, New York: Routledge, 2011.

Attali, Jacques. Hrup: esej o politični ekonomiji glasbe. Ljubljana: Maska, 2008.

Auslander, Philip. V živo: uprizarjanje v mediatizirani kulturi. Ljubljana: Mestno gledališče ljubljansko, 2007.

Auslander, Philip. »Postmodernism and performance«. The Cambridge Companion to Postmodernism. Cambridge: Cambridge University Press, 2004.

Bahn, Curtis et al. „Physicality and Feedback: A Focus on the Body in the Performance of Electronic Music“, 2011. Obiskano 10. 3. 2016. http://www.hass.rpi.edu/public_ html/bahnc2/Activities/writings/physicality_feedback.pdf.

Barbo, Matjaž. Pomen v glasbi in glasba v pomenu. Ljubljana: Znanstvena založba Filozofske fakultete, 2015.

Barbo, Matjaž. Obča muzikologija. Ljubljana: Filozofska fakulteta, 2004.

Beck, Ulrich. Družba tveganja: na poti v neko drugo moderno. Ljubljana: Krtina, 2009.

Blaukopf, Kurt. Glasba v družbenih spremembah. Temeljne poteze sociologije glasbe. Ljubljana: Studia humanitatis, 1993.

Byrne, David. How music works. Edinburgh, London: Canongate, 2013.

Cox, Christoph in Daniel Warner. Audio culture: readings in modern music. New York, London: Continuum, 2007.

Crossley, Nick. The social body. Habit, identity and desire. London: SAGE, 2001.

Debeljak, Aleš. Postmoderna sfinga. Celovec-Salzburg: Wieser, 1989.

Debeljak, Aleš. Na ruševinah modernosti: institucija umetnosti in njene zgodovinske oblike. Ljubljana: Znanstveno in publicistično središče, 1999.

Doğnatan-Dack, Mine. »Artistic research in classical music performance: Truth and politics«. Parse journal \#1: Judgement, 2015. Obiskano 2. 3. 2016. http://parsejournal. $\mathrm{com} /$ issue/ $1 /$. 
Eco, Umberto. "The poetics of open work". V Audio culture: readings in modern music, ur. Christoph Cox in Daniel Warner. New York, London: Continuum, 2007.

Emmerson, Simon. Living electronic music. Aldershot: Ashgate, 2007.

Goehr, Lydia. The imaginary museum of musical works: an essay in the philosophy of music. Oxford: Clarendon press, 1992.

Heaton, Roger. »Contemporary performance practice and tradition«. V Music Performance Research vol. 5, 2012. Obiskano 15. 5. 2016. http://mpr-online.net/Issues/ Volume\%205\%20[2012]/Heaton.pdf.

Hennion, Antoine. "As fast as one possibly can: virtuoso, a truth of musical performance?«. Critical Musicological Reflections. Stan Hawkins, ur.. Burlington: Ashgate, 2012.

Hudej, Franc. »Dualizem duše in telesa». V Teorija in praksa let. 50, 3-4. Ljubljana: Fakulteta za družbene vede, 2013.

Jameson, Fredric. Postmodernizem. Ljubljana: Društvo za teoretsko psihoanalizo, 2001.

Jameson, Fredric. Kulturni obrat. Izbrani spisi o postmoderni, 1983-1998. Ljubljana: Studia humanitatis, 2012.

Keil, Charles in Steven Feld. Music grooves. Chicago: The University of Chicago Press., 1994.

Kopačinska, Patricija: »My Kitchen«. Obiskano 15. 5. 2016. http://patriciakopatchinskaja.com/mykitchen.html.

Kramer, Lawrence. "The virtuoso bofy; or, the two births of musical performance«. Critical Musicological Reflections. Stan Hawkins, ur.. Burlington: Ashgate, 2012.

Krašovec, Primož. »Kultura in finančni kapitalizem v pozni postmoderni (Spremna študija)«. Kulturni obrat. Izbrani spisi o postmoderni, 1983-1998. Ljubljana: Studia humanitatis, 2012.

Kunst, Bojana. "Spremna beseda«. V V živo: uprizarjanje v mediatizirani kulturi. Ljubljana: Mestno gledališče ljubljansko, 2009.

Leech-Wilkinson, Daniel. »The Changing Sound of Music: Approaches to Studying Recorded Musical Performances«, 2009. Obiskano 10. 3. 2016. http://www.charm.rhul. ac.uk/studies/chapters/intro.html.

Leech-Wilkinson, Daniel. »Musicology and Performance», 2014. Obiskano 10. 3. 2016. http://www.rilm.org/historiography/leech.pdf.

McLuhan, Marshall. „Visual and acoustic space«. Audio culture: readings in modern music. Christoph Cox in Daniel Warner, ur.. New York, London: Continuum, 2007.

Moore, Christopher. »Music and Politics, Performance and the Paradigmo of Historical Contextualism«. Music \& Politics 4, Number 1 (Winter, 2010).

Pippen, John R. "Toward a Postmodern Avant-Garde: Labour, Virtuosity, and Aesthetics in an American New Music Ensemble«. Electronic Thesis amd Dissertation Repository. Paper 2446, 2014. Obiskano 6. 1. 2016. http://ir.lib.uwo.ca/cgi/viewcontent. cgi? article $=3698 \&$ context $=$ etd.

Pompe, Gregor. Postmodernizem in semantika glasbe. Ljubljana: Znanstvena založba Filozofske fakultete, 2011.

Pompe, Gregor. »'Modernost' in historična izvajalska praksa«, 2011. Obiskano 15. 5. 2016. http://www.sigic.si/odzven/modernost-in-historicna-izvajalska-praksa. 
Pompe, Gregor. Novi tokovi v glasbi 20. stoletja. Ljubljana: Znanstvena založba Filozofske fakultete, 2014.

Sutherland, Roger. Nove glasbene perspektive. Evropska in ameriška avantgarda $v$ glasbi 20. stoletja.Ljubljana: LUD Šerpa, 2009.

Théberge, Paul. Any sound you can imagine: making music/consuming technology. Hanover, NH: Wesleyan University Press, 1997.

Vila Verde, Teresa. "Assessing the importance of visual/theatrical features in the perception of music by an audience, using sociological tools«. International Symposium on Performance Science, 2007. Obiskano 15. 5. 2016. http://www.performancescience.org/ISPS2007/Proceedings/Rows/28VilaVerde.pdf

Vogrinc, Jože. »Aristotelova teorija filma«. Filmska komedija. Zdenko Vrdlovec, ur.. Ljubljana: Revija Ekran, 1989.

Vogrinc, Jože. Popularna godba. Eseji o poslušanju. Maribor: Subkulturni azil, 2012.

Weber, Max. »Temeljni sociološki pojmiк. Kompendij socioloških teorij, ur. Frane Adam in Matevž Tomšič. Ljubljana: Študentska založba, 2004.

\section{SUMMARY}

Western classical music is largely defied by the distinction between authorship and performance i.e. between formal structure of the musical work and its realisation in sound. This distinction was made possible by the invention of notation and several cultural processes that shaped the position of a classical music performer as inferior to the composer and the musical work.

Before 1800, musical practice was defined by its function - it was either in service of the church or the court. With the rise of the bourgeoisie and capitalism art became a commodity, subdued to the laws of the capitalist market. In order to survive on the market, classical musician had to satisfy the needs of the audience for spectacle and pompousness. This is the birthplace of the romantic virtuoso, who treats music as a means to impress the audience with his musical skills and personality. Romantic virtuosos were highly aware of the importance of their bodily gestures and general appearance.

The bourgeoisie, which was originally a unified social class, became internally stratified by the late $19^{\text {th }}$ and early $20^{\text {th }}$ century. In the context of the intellectual elite, which represented the ideals of culture, knowledge and education, the romantic virtuoso was quickly associated with a charlatan, inappropriate for performing serious music. This was also the time when the work-concept emerged. Lydia Goehr defines work-concept by the following characteristics: a) it is a unique and consciously created composition, b) it can be materialized in score and c) it exists independently of its (potential) performances. When music is considered to be an intellectual activity, its performance must focus on revealing the formal structure of the work and the composer's ideas behind it, while the identity of the performer and his corporeality must remain hidden. This type of performance, in which the musician's body movements and expressions are very limited, is associated with a new type of performer - the modernist virtuoso.

Romantic and modernist virtuosos are what Max Weber would call ideal types. The goal of this research was to confirm the existence of the ideal type called the postmodern virtuoso and to describe his characteristics. But as it turns out, the postmodern virtuoso clearly reflects the features of an era that shapes him. Instead of forming own characteristics, he rather combines and mixes features of previously existing types. The contemporary classical music performer is highly defined by the incorporation of postmodern art into the system of late capitalism and the postmodern loss of the specificity of aesthetic experience (Fredric Jameson). In the postmodern era art is a commodity. Therefore, marketing strategies that were originally designed to sell products of profit-oriented corporations are now often used to sell art and artists. The postmodern virtuoso exists mainly as a brand. As a commodity, classical music must compete with other forms of art and entertainment production and can therefore no longer afford to take an elitist position typical for the art of the late romanticism and modernism. If the romantic and 
modernist virtuosos always presented themselves as separated from the crowd, the postmodernist virtuoso tries to be as close to the audience as possible - in the context of a concert and outside of it. In spite of all postmodern tendencies, contemporary classical music practice still maintains rather strong connections with its romantic in modernist traditions. The ritual structure of a classical music concert contributes to the understanding of music as an intellectual activity, defined by concepts such as composer, performer, audience and musical work. Therefore, the postmodern classical music performer stands in a complex position. On the one hand, he is defined by the strict modernist hierarchical structures and commitment to the Werktreue ideology. On the other hand, under the influence of postmodern culture, he is forced to brand himself as a stage personality and market himself accordingly. The main task of the postmodern virtuoso is to find a proper balance between traditional ideals and contemporary tendencies a proper position between body and mind. 